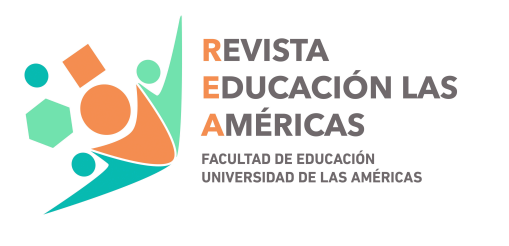

Revista Educación las Américas ISSN: 0719-7128

ccalisto@udla.cl

Universidad de Las Américas

Chile

\title{
Pedagogical and Psychosocial Implications of Quarantine by Covid-19 on Chilean Students
}

\author{
Yeomans Cabrera, María Mercedes; Silva Fuentes, Alicia \\ Pedagogical and Psychosocial Implications of Quarantine by Covid-19 on Chilean Students \\ Revista Educación las Américas, vol. 10, 2020 \\ Universidad de Las Américas, Chile \\ DOI: https://doi.org/10.35811/rea.v10i0.78 \\ Atribución no comercial (CC BY-NC) 4.0
}




\title{
Pedagogical and Psychosocial Implications of Quarantine by Covid-19 on Chilean Students
}

\author{
Implicancias pedagógicas y psicosociales de la cuarentena de Covid-19 en los estudiantes chilenos \\ Maria Mercedes Yeomans Cabrera* \\ DOI: https://doi.org/10.35811/rea.v10i0.78
}

Universidad de Las Américas, Chile

mmyeomans@outlook.com

iD http://orcid.org/0000-0003-2138-3007

Alicia Silva Fuentes

Universidad de Las Américas, Chile

aliciaconstanza.silva@gmail.com

iD http://orcid.org/0000-0001-7398-0167

Received: 12 May 2020

Accepted: 18 June 2020

\begin{abstract}
:
The present academic note presents the scenario that Chilean students are facing in their learning process due to the quarantine by Covid-19. Schools' closure and quarantine might have some psychosocial implications on students' lives that may affect the learning process. Both pedagogical and psychosocial areas are essential to analyze to have a closer perspective of what students are dealing with. Although measures to ensure the student's learning process have been taken, different factors can affect a student's learning from a pedagogical and psychosocial perspective. It is very relevant to have an overview of teaching and learning processes in the pandemic context to make better pedagogical decisions in the future. The need for education authorities to re-elaborate and improve this emergency plan to meet the current educational needs becomes urgent. It is necessary to overcome not only academic issues but psychological and social needs to improve learning experiences. It is also essential to consider stressors that negatively impact students' homeschool educational process, and it is crucial to provide meaningful interactions to socialize and keep strengthening and building relationships inside the scholar community.

KEYWORDS: Quarantine, Education, Students, Covid-19, Psychosocial implications.
\end{abstract}

\section{Resumen:}

La presente nota académica presenta el escenario al que se enfrentan los estudiantes chilenos en su proceso de aprendizaje debido a la cuarentena de Covid-19. El cierre de las escuelas podría tener algunas implicancias en la vida de los estudiantes que podrían afectar el aprendizaje. Tanto el área pedagógica como la psicosocial son importantes de analizar para tener una perspectiva más cercana de lo que los estudiantes están viviendo. Aunque se han tomado medidas para no interrumpir el proceso de aprendizaje, hay diferentes factores que pueden afectar el aprendizaje del estudiante desde una perspectiva pedagógica y psicosocial. Para tomar mejores decisiones pedagógicas en el futuro, es muy pertinente tener una visión general de los procesos de enseñanza y aprendizaje en el contexto de una pandemia. La necesidad de que las autoridades educativas reelaboren y mejoren este plan de emergencia para satisfacer las necesidades educativas actuales se hace urgente. Es necesario superar no sólo las cuestiones académicas, sino también las necesidades psicológicas y sociales, para la mejora de las experiencias de aprendizaje y que consideren aquellos factores de estrés que repercuten negativamente en su proceso educativo y que también proporcionan interacciones significativas para socializar y seguir fortaleciendo y construyendo relaciones dentro de la comunidad educativa.

Palabras Clave: Cuarentena, Educación, Estudiantes, Covid-19, Implicancias Psicosociales.

\section{Author Notes}

* Universidad Internacional Iberoamericana

mmyeomans@outlook.com 


\section{INTRODUCTION}

During the first months of 2020, almost the entire world population has suffered the catastrophic effects of a pandemic of a coronavirus known as Covid-19 (World Health Organization, 2020). By May of the same year, it had cost the lives of hundreds of thousands of people worldwide (Worldometer, 2020) and had taken even the most advanced and prestigious health systems to collapse (Feuer, 2020). However, the impact of this event has not only made authorities and experts question public health administration (Reich, 2020) but also many social paradigms deeply incorporated in our society. Therefore, many of these social structures have been forced to reshape and change perspectives, approaches, and praxis (European Centre for Disease Prevention and Control, 2020). Among the most significant areas affected by Covid-19, it is the educational system which, given the quarantine and social isolation demanded by authorities (Patrinos \& Shmis, 2020), faced school closures affecting about $72 \%$ of students around the world by May 2020 (UNESCO, 2020). For this reason, a deep restructuration and adaptation of approaches, methods, resources, assessment, and lesson planning is necessary (Tam \& El-Azar, 2020).

In the case of Chile, to make pedagogical adaptations, it is necessary to analyze the National Educational Curricular Bases, which were designed and developed by the Ministry of Education (MINEDUC). The bases are the mandatory reference frame that indicates the learning objectives for students to achieve throughout their school trajectory; they present learning objectives for each educational level from which Study Programs have also been developed. These programs aim to sequence learning objectives and offer approximate time distribution and assessment parameters for the school year (Uribe et al., 2018). The Curricular Bases also include Study Plans that establish the minimum classroom hours for each level and its respective subjects (Consejo Nacional de Educación, 2020). Conversely, while Curricular Bases are mandatory for all schools across the country, Study Programs and Plans can be adapted by each school to achieve better learning objectives (Ley General de Educación 20.370, 2019). Study Programs are flexible for teachers to plan and design their lessons (Uribe et al., 2018). These are the standards in which the Chilean educational system sets its foundations for formal instruction to take place inside classrooms nationwide.

Nevertheless, on March 15th, 2020, MINEDUC announced the suspension of all academic activities for all schools across the country-after the confirmed outbreak of Covid-19 in Chilean territoryaltering the prevailing scenario in which education used to take place; despite this closure policy, and as a manner to guarantee student's learning while away from their schools, MINEDUC provided all educational communities with ministerial guidelines to support and assist students throughout the pandemic crisis (Ministerio de Educación, 2020a). These guidelines include a remote learning plan, accessible in MINEDUC's virtual platform, which consists of educational resources aligned with the National Curriculum from 1st to 12th grade; in this platform, students can access guided school texts, complementary resources for students to delve into contents, and guidelines for teachers and directives to remotely guide students and access to a School Digital Library (Ministerio de Educación, 2020b). As a result, it is expected that most of the Chilean students are allowed to continue with their learning autonomously, while guided by teachers and directors.

The current Study Plans and Programs-and therefore learning objectives—can not be accomplished, despite MINEDUC's efforts; Plans and Programs were meant to be applied in traditional classrooms (Uribe et al., 2018). While it is true that most educational virtual resources of the Curricular Bases are available for both teachers and students in virtual platforms (Ministerio de Educación, 2020b), these resources only aim to complement Study Programs that are designed for traditional contexts (Ley General de Educación 20.370, 2019). By contrast, schools' closure and quarantine might have some psychological and social implications on students' lives that may affect the learning process (Wang et al., 2020). Both pedagogical and psychosocial areas are essential to analyze to have a closer perspective of what students are dealing with. 


\section{The TeAChing PRocess IN PANDEMIC CONTEXT}

In early March 2020, once Chile entered phase 4 of the pandemic, meaning the outbreak was communityleveled (Gobierno de Chile, 2020), the government announced the full suspensions of all academic activities for the public, subsidized and private schools across the country (Ministerio de Educación, 2020b). This policy responded to international standards of the World Health Organization whose protocol indicated social distancing as the most effective measure to avoid future and significant contagion; this policy prevented all Chilean students from continuing their formal instruction (Centers for Disease Control and Prevention, 2020). For instance, even learners from cities that had not yet presented Covid-19 cases-or had them under control-were not allowed to attend their schools as they remain closed until authorities present a new protocol. Therefore, by May 2020, the complete educational spectrum of formal instruction within Chilean frontiers remained suspended and inactive awaiting for future governmental guidelines to proceed (Ministerio de Educación, 2020c).

As a consequence of the previous announcement, the Chilean Ministry of Education presented a pack of ministerial guidelines for Covid-19 regarding administration, teaching, and resources (Ministerio de Educación, 2020b). Among these guidelines, the Ministry implements a complementary Remote Learning Plan and announces future training for teachers on online education (Ministerio de Educación, 2020b). Nonetheless, this plan — which involves online lessons for Math and Language, leaving other subjects open for teacher's adaptation of study plans-has been sharply criticized by the Teacher's National Committee; experts claim that given the inequality in resources of Chilean learners and teachers, this plan is not sufficient to ensure successful learning processes from home (Cornejo \& González, 2020). Hence, the need for educational authorities to re-elaborate and improve this emergency plan to meet the current educational needs and reality becomes urgent.

\section{The LEARNING PROCESS IN PANDEMIC CONTEXT}

The learning process may be affected by the psychological effects of social distancing on learners; homeschool education should address these issues to present an alternative approach to education that meets the academic and emotional needs of learners in such harsh social contexts (Wang et al., 2020).

Social distancing and isolation can severely affect and alter human behavior and emotional balance, especially for those more vulnerable to environmental influence, such as children and adolescents (Orhilés et al., 2020). Studies on the psychological impact of quarantine for this age-group indicate that social isolation leads to boredom, tendency to access inadequate information, frustration for lack of in-person contact with friends, classmates, and teachers, and lack of personal space at home (Wang et al., 2020). For instance, a lockdown teenager can feel tempted to look for more meaningful ways to interact with classmates or teachers and can access online platforms that do not meet educational criteria, causing even more confusion in students and increasing frustration. Moreover, the previously mentioned stressors can also negatively impact their learning processes, especially when governmental initiatives to face the pandemic do not meet educational reality and needs (Wang et al., 2020). As the emotional state of students plays a central role in learning $(\mathrm{Ni}, 2012)$, the impact of current social distancing policies and the unsatisfying experience with remote ministerial alternatives to keep education going while in quarantine prevent the learning process from completing its cycle (Wang et al., 2020). For instance, for a student who is daily struggling with anxiety from lack of personal space at home, it can be tough to focus or complete tasks that demand quiet areas or concentration. Those types of context may affect students' performance and decrease their motivation for future assignments.

Consequently, social distancing and home confinement can severely affect the mental health of adolescents; they can make students prone to school failure or discouragement (Orhilés et al., 2020). 
These issues can even worsen when authorities do not present the school community with rewarding and successful solutions to face the immediate effects of the crisis and mitigate its psychological and pedagogical repercussions (Wang et al., 2020). For example, unsatisfying experiences with unproperly designed online courses may lead to academic failure. It may be caused by frustration for not being able to accurately use online platforms or anxiety due to a lack of resources to complete tasks, among others.

\section{STUDENTS' SOCIALIZATION IN PANDEMIC CONTEXT}

Even isolated from traditionally known classmates, homeschool students can sustain meaningful and constant interactions with other learners and peers in online contexts, as required by the pandemic (Chen, 1999). Despite common belief regarding the uniqueness and value of social interactions of classmates inside the classroom and schools, homeschool learners have proven to be equally and even better assessed when it comes to building significant relationships and have successful interactions with peers and adults (Medlin, 2013). In the current context, it may be assumed that these interactions do not necessarily take place in extracurricular instances. They may also take place in educational contexts in which students share knowledge, experiences, and reflections with other homeschool learners via online platforms specially designed for these purposes.

Social restrictions experienced in Chile and most countries by the Covid-19 pandemic have driven authorities to elaborate strategies to address education from home, at national levels; considering the changes that students are experiencing, it is crucial to be aware of the impact on the psychological development of learners (Ray, 2013). While it is true that isolation and confinement negatively impact learning, it is also feasible to find gains from homeschool settings regarding peer interaction, self-concept, leadership skills, family cohesion, participation in community service, and self-esteem (Woyshner, 1995). For instance, disruptive and damaging social interaction commonly seen at schools_-such as bullying and abuse-could more likely to be controlled and prevented in online homeschool settings given students' traits and available resources for monitoring.

There is a possible positive psychological impact that homeschool settings can offer learners; they also may involve long term contributions in academic development at all educational stages (Ray, 2010). Homeschooled students are more self-sufficient, controlled, goal-oriented, and self-regulated when motivated by social cognitive constructs (Ray, 2004). For example, given these traits, online homeschool students are more likely to commit to their work and their learning process and experience; homeschool settings for online courses may offer a successfully tested alternative to overcome the crisis and empower students in the process.

Consequently, online homeschool education must incorporate instances of significant social interactions to build meaningful relationships inside school community members to grant students the necessary tools and knowledge to face social, educational, and personal challenges to come once the pandemic is overcome. These instances must be carefully planned and designed to cover curricular contents adequately, and at the same time, appeal to meaningful social interactions to mitigate the negative psychological impact of an online homeschool education under quarantine parameters. For instance, homeschooled online courses can include virtual tours to online museums or expositions for both teachers and learners to address study plans. At the same time, they may interact for educational purposes in meaningful ways that reduce frustration prompted from social isolation and lack of in-person interaction. 


\section{Conclusions}

It is necessary to analyze the current socio-political scenery and governmental response to it to identify possible adaptations from traditional classes to online classes and fulfill learning objectives. The need for education authorities to re-elaborate and improve this emergency plan to meet the current educational needs becomes urgent. In the same line, it is also urgent to present not only students but also the full school community useful and successful contention plans to face the crisis under the given social context.

It is necessary to analyze the current psychological and pedagogical impact of social restriction and online homeschooled education on young learners to perform adaptations from traditional educational settings to an online one, to achieve curricular objectives successfully. It is needed for authorities to address this issue and urgently look for solutions to mitigate the psychological impact of home confinement. Educational authorities must come up with useful learning platforms to improve learning experiences and reduce the negative repercussions of psychological issues of students in learning processes. Authorities must design learning plans that effectively address the curricular contents in friendly and meaningful ways, improving learning experiences, and considering stressors that negatively impact their homeschool educational process.

Educational authorities must also come up with platforms and online instances that allow not only students but the school community in meaningful general interactions to socialize and keep strengthening and building relationships inside the community. Acknowledging that mental health becomes a more significant issue as the pandemic remains, online homeschool initiatives present a meaningful contribution to help to face the current scenario with positive traits. They can improve not only current learners' present but also future citizens' lives. Young learners struggling with a negative impact on the mental health of social isolation can find natural and mitigating solutions on homeschool education that can even improve their current emotional, academic, and personal growth.

IMPLICANCIAS PEDAGógICAS Y PSICOSOCIALES DE LA CUARENTENA DE COVID-19 EN LOS ESTUDIANTES CHILENOS

\section{INTRODUCCIÓN}

Durante los primeros meses de 2020, casi toda la población mundial ha sufrido los efectos catastróficos de la pandemia de un virus corona conocido como Covid-19 (World Health Organization, 2020) que, para mayo del mismo año, ha costado la vida a cientos de miles de personas en todo el mundo (Worldometer, 2020) y ha llevado al colapso incluso a los sistemas de salud más avanzados y prestigiosos (Feuer, 2020). No obstante, el impacto de este acontecimiento no sólo ha hecho que las autoridades y los expertos cuestionen la administración de la salud pública (Reich, 2020) sino también muchos paradigmas sociales profundamente incorporados en nuestra sociedad, lo que ha obligado a muchas de estas estructuras sociales a remodelar y cambiar las perspectivas, los enfoques y la praxis (European Centre for Disease Prevention and Control, 2020). Entre las áreas más significativas afectadas por Covid-19 se encuentra el sistema educativo que, dada la cuarentena y el aislamiento social que exigen las autoridades (Patrinos \& Shmis, 2020), se enfrentó al cierre de escuelas que afectó a cerca del $72 \%$ de los estudiantes de todo el mundo en mayo de 2020 (UNESCO, 2020). Por esta razón, se exige con urgencia una profunda reestructuración y adaptación de los enfoques, métodos, recursos, evaluación y planificación de lecciones utilizados para aplicar los planes de estudio mientras se está en cuarentena (Tam \& El-Azar, 2020).

En el caso de Chile, para realizar adaptaciones pedagógicas es necesario analizar las bases curriculares nacionales de educación; las bases son el marco de referencia obligatorio que indica los objetivos de aprendizaje que deben alcanzar los alumnos a lo largo de su trayectoria escolar, presentan los objetivos de 
aprendizaje para cada nivel educativo y a partir de los cuales se desarrollan los programas de estudio; estos programas buscan secuenciar los objetivos de aprendizaje, ofrecen una distribución temporal aproximada y parámetros de evaluación para el año escolar (Uribe et al., 2018). Las bases curriculares también incluyen planes de estudio que establecen las horas mínimas de clase para cada nivel y sus respectivas asignaturas (Consejo Nacional de Educación, 2020). Por otra parte, si bien las bases curriculares son obligatorias para todas las escuelas del país, los programas y planes de estudio pueden ser adaptados por cada escuela para lograr mejor los objetivos de aprendizaje (Ley General de Educación 20.370, 2019); los programas de estudio son flexibles para que los maestros planifiquen y diseñen sus lecciones (Uribe et al., 2018). Estos son los estándares en los que el sistema educativo chileno establece sus bases para que la instrucción formal tenga lugar dentro de las aulas en todo el país.

Sin embargo, el 15 de marzo de 2020, el Ministerio de Educación (MINEDUC) anunció la suspensión de todas las actividades académicas de todos los colegios del país tras el brote confirmado de Covid-19 en territorio chileno, lo que alteró así el escenario imperante en el que se desarrollaba la educación; a pesar de esta política de cierre, y como una forma de garantizar el aprendizaje de los estudiantes mientras se encontraban fuera de sus colegios, el MINEDUC proporcionó a todas las comunidades educativas directrices ministeriales para apoyar y asistir a los estudiantes durante la crisis de la pandemia (Ministerio de Educación, 2020a). Estas directrices incluyen un plan de aprendizaje a distancia, accesible en la plataforma virtual del MINEDUC, que consiste en recursos educativos alineados con el Plan Nacional de Estudios de $1^{\circ}$ Básico a IVo Medio; en esta plataforma, los estudiantes pueden acceder a textos escolares guiados, recursos complementarios para que los estudiantes profundicen en los contenidos y directrices para los maestros y directivas para guiar a los estudiantes a distancia y acceder a una Biblioteca Digital Escolar (Ministerio de Educación, 2020b). Como resultado, se espera que la mayoría de los estudiantes chilenos puedan continuar de manera autónoma con su aprendizaje mientras son guiados por los profesores y directores.

A pesar de los esfuerzos del MINEDUC por cubrir los objetivos de aprendizaje curricular mientras dure el cierre de escuelas por el brote de Covid-19, los actuales planes y programas de estudio (y por lo tanto los objetivos de aprendizaje) no pueden ser cumplidos a cabalidad ya que fueron concebidos para ser aplicados en las aulas tradicionales (Uribe et al., 2018) y no en la modalidad de aprendizaje a distancia. Si bien es cierto que la mayoría de los recursos educativos virtuales de las bases curriculares están actualmente disponibles tanto para los profesores como para los estudiantes en plataformas virtuales (Ministerio de Educación, 2020b), estos recursos solo pretenden complementar los programas de estudio diseñados para ser aplicados por los profesores, no virtualmente sino de manera tradicional (Ley General de Educación 20.370, 2019). Por otra parte, el cierre de las escuelas y la cuarentena podrían tener algunas implicancias psicológicas (como son la ansiedad y la frustración) e implicancias sociales en la vida de los estudiantes que podrían afectar al proceso de aprendizaje (Wang et al., 2020). Es importante realizar un análisis descriptivo tanto en el área pedagógica como la psicosocial durante el contexto de cuarentena para tener una perspectiva más cercana de lo que los estudiantes chilenos están viviendo.

\section{El PRoceso de ENSEÑANZA EN EL CONTEXTO DE PANDEMia}

A principios de marzo de 2020, una vez que Chile entró en la fase 4 de la pandemia (lo que significa que el brote se produjo a nivel comunitario) (Gobierno de Chile, 2020), el gobierno anunció la suspensión total de todas las actividades académicas de las escuelas públicas, subvencionadas y privadas de todo el país (Ministerio de Educación, 2020b). Esta política respondió a los estándares internacionales de la Organización Mundial de la Salud, cuyo protocolo indicaba el distanciamiento social como la medida más efectiva para evitar futuros y grandes contagios (Centers for Disease Control and Prevention, 2020), lo que impidió que todos los estudiantes chilenos continuaran su instrucción formal. Es así como, incluso a los alumnos de ciudades que aún no habían presentado casos de infección por Covid-19 o los tenían bajo control, no se les permitía asistir 
a sus escuelas, ya que estas permanecían cerradas hasta que las autoridades presentaran un nuevo protocolo. Por lo tanto, para mayo de 2020, todo el espectro educativo de la instrucción formal dentro de las fronteras chilenas permanecía suspendido e inactivo en espera de futuras directrices gubernamentales para proceder (Ministerio de Educación, 2020c).

Como consecuencia del anuncio anterior, el Ministerio de Educación de Chile presentó un paquete de directrices para el Covid-19 en relación con la administración, la enseñanza y los recursos entre las que pone en práctica un plan de aprendizaje a distancia complementario y anuncia la futura capacitación de los maestros en la educación en línea (Ministerio de Educación, 2020b). Sin embargo, este plan, que implica lecciones en línea para Matemáticas y Lenguaje para dejar a las otras asignaturas abiertas para la adaptación de los planes de estudio por parte de los propios profesores, ha sido fuertemente criticado por el Colegio de Profesores quienes afirman que dada la desigualdad de recursos tecnológicos disponibles entre los alumnos y profesores, este plan no es suficiente para asegurar el éxito de los procesos de aprendizaje desde el hogar (Cornejo \& González, 2020). De ahí que sea urgente la necesidad de que las autoridades educativas reelaboren y mejoren este plan de emergencia para satisfacer las necesidades educativas actuales y la realidad.

\section{El PRoceso de APRENDIZAJE EN EL CONTEXTO DE PANDEMIA}

El proceso de aprendizaje puede verse afectado por los efectos psicológicos del distanciamiento social en los educandos (ansiedad, depresión, frustración, entre otros); la educación en el hogar-escuela debe abordar estas cuestiones a fin de presentar un enfoque alternativo de la educación que satisfaga las necesidades académicas y emocionales de los educandos en contextos sociales tan duros (Wang et al., 2020).

En el caso de niños y adolescentes, quienes son más vulnerables a la influencia del entorno, el aislamiento les pueden afectar gravemente y alterar su comportamiento y el equilibrio emocional (Orhilés et al., 2020). Los estudios sobre el impacto psicológico de la cuarentena para este grupo de edad indican que el aislamiento social conduce al aburrimiento, la tendencia a acceder a información inadecuada, la frustración por la falta de contacto personal con amigos, compañeros de clase y maestros y la falta de espacio personal en el hogar (Wang et al., 2020). Por ejemplo, un adolescente aislado, en lugar de atenerse a las actividades en línea con fines académicos puede sentirse tentado a buscar formas más significativas de interactuar con sus compañeros de clase o profesores y acceder a otras plataformas que no cumplen los criterios educativos. Además, los factores de estrés mencionados anteriormente también pueden afectar negativamente a sus procesos de aprendizaje, especialmente cuando las iniciativas gubernamentales para hacer frente a la pandemia no se ajustan a la realidad y las necesidades educativas (Wang et al., 2020) al no considerar todas las realidades existentes (baja calidad o ausencia de internet, acceso restringido a computadores, etc.). Dado que el estado emocional de los estudiantes desempeña un papel central en el aprendizaje (Ni, 2012), el impacto de las actuales políticas de distanciamiento social y la experiencia insatisfactoria de las alternativas remotas ministeriales para mantener la educación mientras se está en cuarentena impiden que el proceso de aprendizaje complete con éxito su ciclo (Wang et al., 2020). Por ejemplo, para un estudiante que lucha diariamente con la ansiedad por la falta de espacio personal en su casa, puede ser extremadamente difícil concentrarse o completar las tareas que requieren de espacios libres de distracciones, lo que afecta al rendimiento del estudiante y disminuye su motivación para futuras tareas.

En consecuencia, el distanciamiento social y el encierro en el hogar pueden afectar gravemente la salud mental de los adolescentes, por lo que los estudiantes estarían más propensos al fracaso o al desaliento escolar (Orhilés et al., 2020). De hecho, estas cuestiones pueden incluso empeorar cuando las autoridades no presentan a la comunidad escolar soluciones gratificantes y satisfactorias para hacer frente a los efectos inmediatos de la crisis y mitigar sus repercusiones psicológicas y pedagógicas (Wang et al., 2020). Por ejemplo, las experiencias insatisfactorias con cursos en línea mal diseñados pueden dar lugar a un fracaso académico 
causado por la frustración por no poder utilizar con precisión las plataformas en línea o la ansiedad por la falta de recursos para completar las tareas.

\section{LA SOCIALIZACIÓN DE LOS ESTUDIANTES EN EL CONTEXTO DE LA PANDEMIA}

Aunque aislados de sus compañeros de clase tradicionalmente conocidos, los estudiantes que estudian en casa pueden mantener interacciones significativas y constantes con otros estudiantes y compañeros (video llamadas, chats, entre otros), incluso en contextos en línea a causa de la pandemia (Chen, 1999). A pesar de la creencia común sobre la singularidad y el valor de las interacciones sociales de los compañeros de clase dentro del aula y de la escuela, los estudiantes que reciben educación en el hogar han demostrado ser igual e incluso mejor evaluados cuando se trata de establecer relaciones significativas y tener interacciones exitosas con sus pares y adultos (Medlin, 2013). En el contexto actual, se puede asumir que esas interacciones no se producen necesariamente en instancias extracurriculares, sino también en contextos educativos en los que pueden compartir conocimientos, experiencias y reflexiones con otros alumnos de la enseñanza en el hogar a través de plataformas en línea especialmente diseñadas para esos fines.

Las restricciones sociales experimentadas en Chile y en la mayoría de los países por la pandemia de Covid-19 han llevado a las autoridades a elaborar estrategias para abordar la educación desde el hogar a nivel nacional tales como aprendizaje a distancia, contención emocional, orientación docente y adaptación del calendario escolar, entre otras (Ministerio de Educación, 2020a); teniendo en cuenta el ambiente de cambios, es muy importante ser conscientes de las repercusiones en el desarrollo psicológico de los alumnos (Ray, 2013). Si bien es cierto que el aislamiento y el encierro repercuten negativamente en el aprendizaje, también es factible encontrar beneficios que pueden obtenerse de los entornos hogar-escuela en lo que respecta a la interacción entre pares, el autoconcepto, las aptitudes de liderazgo, la cohesión familiar, la participación en el servicio comunitario y la autoestima (Woyshner, 1995). Por ejemplo, la interacción social perturbadora y perjudicial que se observa comúnmente en las escuelas, como la intimidación y el abuso, podría controlarse y prevenirse con mayor probabilidad en los entornos hogar-escuela en línea, dadas las características propias de los estudiantes y los recursos disponibles para la vigilancia.

Existe un posible impacto psicológico positivo que los entornos de la educación en el hogar pueden ofrecer a los alumnos; también pueden implicar contribuciones a largo plazo en el desarrollo académico en todas las etapas educativas (Ray, 2010), como estudiantes más autosuficientes, controlados, orientados a objetivos y autoregulados cuando están motivados por construcciones cognitivas sociales (Ray, 2004). Por ejemplo, dadas estas características, es más probable que los estudiantes que reciben educación en línea en el hogar se comprometan con su trabajo y con su propio proceso y experiencia de aprendizaje; los entornos de educación en el hogar para cursos en línea pueden ofrecer una alternativa probada con éxito para superar la crisis y potenciar a los estudiantes en el proceso.

Por consiguiente, la educación en línea para la enseñanza en el hogar debe incorporar instancias de interacciones sociales significativas para construir relaciones valoradas dentro de los miembros de la comunidad escolar y aprovechar, al mismo tiempo, los rasgos positivos que este tipo de instrucción desarrolla comúnmente en los alumnos; así se otorgará a los estudiantes las herramientas y los conocimientos necesarios para enfrentar los desafíos sociales, educativos y personales que se presentarán una vez superada la pandemia. Estas instancias deben planificarse y diseñarse cuidadosamente para cubrir eficazmente los contenidos curriculares, y al mismo tiempo apelar a interacciones sociales significativas para mitigar el impacto psicológico negativo de una educación en línea en el hogar y la escuela bajo parámetros de cuarentena. Por ejemplo, los cursos en línea de educación en el hogar pueden incluir interacciones grupales con fines educativos donde se comente en relación a visitas virtuales a museos o exposiciones en línea. Tanto los maestros como los alumnos abordarán los planes de estudio y al mismo tiempo habrá interacción con fines 
educativos de manera significativa para reducir la frustración provocada por el aislamiento social y la falta de interacción en persona.

\section{Conclusiones}

Para identificar las posibles adaptaciones de las clases tradicionales a las clases en línea y cumplir con los objetivos de aprendizaje, es necesario analizar el escenario sociopolítico actual y la respuesta gubernamental al mismo. Se hace urgente la necesidad de que las autoridades educativas reelaboren y mejoren este plan de emergencia para satisfacer las necesidades educativas actuales. En la misma línea, también es urgente presentar no sólo a los estudiantes sino a toda la comunidad escolar planes de contención útiles y exitosos para enfrentar la crisis en el contexto social dado.

Para realizar adaptaciones de los entornos educativos tradicionales a uno en línea y lograr con éxito los objetivos curriculares, es necesario analizar el impacto psicológico y pedagógico actual de la restricción social y de la educación en línea en el hogar en los estudiantes jóvenes. Es relevante que las autoridades aborden esta cuestión y busquen urgentemente soluciones para mitigar el impacto psicológico del confinamiento en el hogar (ansiedad, estrés, depresión, frustración, entre otros). Las autoridades educativas deben crear plataformas de aprendizaje altamente accesibles, amigables y que minimicen los problemas técnicos para mejorar las experiencias de aprendizaje y reducir las repercusiones negativas de los problemas psicológicos de los estudiantes en los procesos educativos.

Las autoridades educativas también deben idear plataformas e instancias en línea que permitan no solo a los estudiantes, sino a la comunidad escolar en general, interacciones significativas para socializar y seguir fortaleciendo y construyendo relaciones dentro de la comunidad. Se debe reconocer que la salud mental se convierte en un problema mayor a medida que la pandemia continúa, las iniciativas en línea de educación en el hogar presentan una contribución significativa para ayudar a enfrentar el escenario actual con rasgos positivos que pueden mejorar no sólo la vida de los actuales alumnos, sino también la de los futuros ciudadanos. Los estudiantes jóvenes que luchan contra el impacto negativo en la salud mental del aislamiento social pueden encontrar soluciones cómodas y mitigantes en la educación en el hogar que incluso pueden mejorar su actual crecimiento emocional, académico y personal.

\section{REFERENCES}

Centers for Disease Control and Prevention. (2020). Coronavirus Disease 2019 ( COVID-19) Social Distancing, Quarantine, and Isolation. https://www.cdc.gov/coronavirus/2019-ncov/prevent-getting-sick/social-distancin g.html

Chen, E. J. (1999). Computer use in home school families. Harvard University. https://search.proquest.com/docview /304502861

Consejo Nacional de Educación. (2020). Planes y Programas De Estudio. https://www.cned.cl/planes-y-programasde-estudio

Cornejo, R., \& González, E. (2020). El Mineduc y su postura frente a la pandemia\#: ¿una mirada pública? Diario y Radio U Chile. https://radio.uchile.cl/2020/04/20/el-mineduc-y-su-postura-frente-a-la-pandemia-una-mirada -publica/

European Centre for Disease Prevention and Control. (2020). Considerations relating to social distancing measures in response to the COVID-19 epidemic (Issue March).ECDC.https://www.ecdc.europa.eu/sites/default/files/ documents/covid-19-social-distancing-measuresg-guide-second-update.pdf

Feuer, W. (2020). WHO officials warn health systems are "collapsing" under coronavirus: "This isn't just a bad flu season.” CNBC. https://www.cnbc.com/2020/03/20/coronavirus-who-says-health-systems-collapsingthis-isnt-just-a-bad-flu-season.html 
Gobierno de Chile. (2020). Chile enters the Stage 4 Coronavirus transmission scenario and President Piñera announces the closure of the borders and secures the supply chain. Gob.cl https://www.gob.cl/en/news/chile-enters-stage-4-coronavirus-transmission-scenario-and-presidentpinera-announces-closure-borders-and-secures-supply-chain/

Ley General de Educación 20.370, Biblioteca del Congreso Nacional (2019). https://www.leychile.cl/N? $\mathrm{i}=1014974 \& \mathrm{f}=2019-06-27 \& \mathrm{p}=$

Medlin, R. G. (2013). Homeschooling and the Question of Socialization Revisited. Peabody Journal of Education, 88(3), 284-297. https://doi.org/10.1080/0161956X.2013.796825

Ministerio de Educación. (2020a). Orientación al sistema escolar en contexto COVID-19. División Educación General. https://bibliotecadigital.mineduc.cl/bitstream/handle/20.500.12365/14311/ OrientContexCOVID19_2703.pdf?sequence $=1$ \&isAllowed $=\mathrm{y}$

Ministerio de Educación. (2020b). Orientaciones Mineduc Covid-19. https://www.mineduc.cl/wp-content/ uploads/sites/19/2020/03/OrientacionesMineduc_COVID19.pdf

Ministerio de Educación. (2020c). Se extiende período de suspensión de clases. Mineduc. https://www.mineduc.cl/ se-extiende-periodo-de-suspension-de-clases/

Ni, H. (2012). The effects of affective factors in SLA and pedagogical implications. Theory and Practice in Language Studies. https://doi.org/10.4304/tpls.2.7.1508-1513

Orhilés, M., Morales, A., Delveccio, E., Mazzeschi, C., \& Espada, J. (2020). Immediate psychological effects of the COVID-19 quarantine in youth from Italy and Spain. https://doi.org/10.31234/osf.io/5bpfz

Patrinos, H., \& Shmis, T. (2020). Can technology help mitigate the impact of COVID-19 on education systems in Europe and Central Asia? World Bank. https://blogs.worldbank.org/europeandcentralasia/can-technologyhelp-mitigate-impact-covid-19-education-systems-europe-and

Ray, B. D. (2004). Homeschoolers On To College\#: What Research Shows Us. Journal of College Admission, 185, 511. https://files.eric.ed.gov/fulltext/EJ682480.pdf

Ray, B. D. (2010). Academic achievement and demographic traits of homeschool students: A nationwide study. Academic Leadership, 8(1), 7. https://scholars.fhsu.edu/cgi/viewcontent.cgi?article=1366\&context=alj

Ray, B. D. (2013). Home-schooling Associated with Beneficial Learner and Societal Outcomes but Educators Do Not Promote It. Peabody Journal of Education, 88(3), 324-341. https://doi.org/10.1080/0161956X.2013.798508

Reich, R. (2020). America has no real public health system coronavirus has a clear run. The Guardian. https://www .theguardian.com/

Tam, G., \& El-Azar, D. (2020). 3 Ways the Coronavirus Pandemic Could Reshape Education. World Economic Forum. https://www.weforum.org/agenda/2020/03/3-ways-coronavirus-is-reshaping-educationand-what-changes-might-be-here-to-stay

UNESCO. (2020). COVID-19 Educational Disruption and Response. https://en.unesco.org/covid19/educationresp onse

Uribe, M., Vanni, X., Pinares, C., \& Rozas, J. (2018). Marco para la Buena Dirección y el Liderazgo Escolar. Centro de Perfeccionamiento, Experimentación e Investigaciones Pedagógicas. https://doi.org/10.1109/ URSIGASS.2011.6050703

Wang, G., Zhang, Y., Zhao, J., Zhang, J., \& Jiang, F. (2020). Mitigate the effects of home confinement on children during the COVID-19 outbreak. The Lancet, 395(10228), 945-947. https://doi.org/10.1016/S0140-6736(20 )30547-X

World Health Organization. (2020). Coronavirus. WHO. https://www.who.int/health-topics/coronavirus\#tab=ta b_1

Worldometer. (2020). Covid-19 Coronavirus Pandemic. Worldometer.info. https://www.worldometers.info/coron avirus/ 
ReVista Educación las AMÉricas, 2020, vol. 10, JANUARY-JuLY, ISSN: 0719-7128

Woyshner, C. (1995). A Sense of Self: Listening to Homeschooled Adolescent Girls. Harvard Educational Review, 66(3), 693. https://search.proquest.com/openview/9da74087c683c225da911955efa70490/1 ?pq-origsite=gsc holar\&cbl= 41677

CC BY-NC 